\title{
GCU
}

Glasgow Caledonian

University

University for the Common Good

\section{Social work and countering violent extremism in Sweden and the UK}

Finch, Jo; Jonsson, Jessica H. ; Kamali, Masoud; McKendrick, David

Published in:

European Journal of Social Work

DOI:

10.1080/13691457.2019.1657803

Publication date:

2022

Document Version

Author accepted manuscript

Link to publication in ResearchOnline

Citation for published version (Harvard):

Finch, J, Jonsson, JH, Kamali, M \& McKendrick, D 2022, 'Social work and countering violent extremism in Sweden and the UK', European Journal of Social Work, vol. 25, no. 1, pp. 119-130.

https://doi.org/10.1080/13691457.2019.1657803

\section{General rights}

Copyright and moral rights for the publications made accessible in the public portal are retained by the authors and/or other copyright owners and it is a condition of accessing publications that users recognise and abide by the legal requirements associated with these rights.

Take down policy

If you believe that this document breaches copyright please view our takedown policy at https://edshare.gcu.ac.uk/id/eprint/5179 for details of how to contact us. 
Social Work and Countering Violent Extremism in Sweden and the UK

European Journal of Social Work

Finch, J. ${ }^{*}$ Jönsson, J. Kamali, M. and McKendrick, D.

\begin{abstract}
Social Work in Europe, is now being tasked with managing the "problems" of terrorism, i.e supporting those affected by terrorist attacks, managing returnees affiliated with Terrorist groups in the Middle East, or, as will be discussed here, identifying those at risk from radicalisation and extremism. Both Britain and Sweden have Counter-Terrorism policies, but recent developments in both countries, have made it a statutory requirement for social workers, to work within such policies. This paper seeks to explore the policies in both countries utilising a comparative approach, to consider the similarities in not only policy and practice, but also in the ethical consequences such policies pose for social workers across Europe. The exploration considers; the extent to which anti-radicalisation policies influence social work practices in Sweden and the UK and how they might undermine social work as a human rights profession. The results indicate that anti-radicalisation policies run the risk of reducing social work to become a 'policing profession' practicing social control. This has substantial consequences for social work and its global ethics, which should be considered and struggled against by social workers committed to principles of social justice and human rights.
\end{abstract}

Keywords:

Social work, counter-terrorism, radicalisation, extremism, racism, Islamophobia, othering

${ }^{*}$ corresponding author

Dr Jo Finch

Reader in Social Work

Cass School of Education and Communities

University of East London

Water Lane

London

E15 4LZ

Tel 44(0) 2082232932

Email J.Finch@uel.ac.uk

Twitter@jojofinchers 
Dr Jessica H. Jönsson

Senior Lecturer in Social Work

School of Law, Psychology and Social Work

Örebro University

SE-701 82, Örebro, Sweden

E-mail: jessica-hanna.jonsson@oru.se

Professor Masoud Kamali

Independent Scholar, Uppsala, Sweden

E-mail: masokama68@gmail.com

David McKendrick

Lecturer in Social Work,

Department of Social Work,

Glasgow Caledonian University,

Cowcaddens Road,

Glasgow,

G5 OHT,

(44) 1413318994

david.mckendrick@gcu.ac.uk

Twitter@bonklesoul

\section{Introduction}

Terrorism is not a new phenomena, indeed, terrorist events have been reported throughout history (Hoffman 2006; Koomen and Van Der Pligt, 2016), recognising definitional debates about the term 'terrorism' (Horgan, 2014; Smelser, 2007). Concerns about terrorism across the globe therefore, existed long before the terrorist attack on the World Trade Centre in September 2001. Indeed, the British co-authors of this paper grew up hearing about the 'The Troubles' that took place in Northern Ireland and recall IRA bomb attacks in a number of cities in mainland Britain. Nonetheless, the $9 / 11$ attack prompted a muscular response by many Western democracies, with a number updating their anti-terrorism policies, as this article documents in terms of Sweden and the UK. 
What is 'new' however, is the increasing role that many caring professions are now playing in both the identification of people at risk of extremism and radicalisation, and preventing them from developing views that may lead them to be partake in terrorist activities in mainland Europe and beyond. Social work activities across Europe may include; managing returnees from conflict zones, preventing people (and families) from travelling to middle east war zones and managing the risk caused by those deemed to have radical and extremist views. It is important to note at the outset that whilst both Sweden and the UK's countering violent extremism policies, discusses many forms of extremism, i.e right and left wing extremism, the current focus for social work in both Sweden and the UK has largely taken place in relation to concerns about Islamic extremism as we go on to document.

The aim of this article to undertake a comparative analysis of countering violent extremism (CVE) policies in both Sweden and the UK and to consider the wider implications for social workers engaging in such work. The following key questions have guided the work: Firstly, how might anti-radicalisation policies influence the practices of social work in Sweden and the UK, and in particular, influence social work as a human rights profession, and secondly, how can social workers re(act) against securitisation policies? We have chosen to focus on the UK and Swedish context, given their differing histories of colonisation and very different approaches to welfare. Notwithstanding differences between the UK and Sweden, the neo-liberal transformations during the last three decades in Sweden have also led to increasing securitisation policies which can be compared to what is happening in the UK (Jönsson, 2019; Kamali, 2015; Kamali \& Jönsson 2018). The neo-liberal transformation of Sweden and the retreat of its strong welfare state is a reality which often overlooks by the established image of the country as the champion of welfare and solidarity. Concerns have been raised in both the UK and Sweden, that such policies are being implemented in not only a research vacuum but without the level of critical academic and practice debate that such policies should provoke (McKendrick \& Finch, 2017). Critical questions such as what is currently, and what should be the social work role in countering violent extremism are subsequently explored.

This article explores an emerging securitised welfare, with distinct neo-liberal and racist undertones, as well as a state sponsored endorsement of the continued othering and suspicion of both Muslim and migrant communities, in both the UK and Sweden. As such, a greater historical contextualisation, an increased awareness of its potential consequences for the profession and a continuous robust academic discussion on the relationship of this work, to an 
increased neoliberalisation of a profession steeped in emancipatory and liberatory discourse must be explored. The discussion begins with an overview of the Swedish policy context.

\section{The Swedish Policy Context}

Initially, the World Trade Centre attacks, whilst shocking and receiving much media coverage in Sweden, were not considered by Swedish politicians to be a security concern, given that Sweden had not taken part in the US-led attack on Iraq. This non-interventionist position however, gradually changed, not least when Sweden joined the international forces in the military intervention in Afghanistan. Swedish anti-terror measures were subsequently introduced and were highly influenced by both the UK and it's PREVENT programme (Herz, 2016) and the Obama administration's anti-terror Countering Violent Extremism programme (Nguyen, 2016).

Most recently in Sweden, the Syrian war and the so called 'terrorist-trips' to Syria have reinforced the government's concern about 'radicalisation' of youths with Muslim backgrounds who are mainly concentrated in marginalised urban areas. The debate on the government's duty to combat terrorism among Muslims with immigrant backgrounds as a 'threat' to Swedish society, has led to the appointment of a 'coordinator of anti-radicalisation', former minister of integration Mona Sahlin in 2008. Her remit was to require municipalities to have antiradicalisation programmes and strategies to prevent radicalisation. Given the fact that municipalities are the major employers of social work in Sweden, the governmental coordinators' advice and guidelines in respect of countering violent extremism, has been highly influential on the practices of social workers, particularly in marginalised areas. In many areas for example, common meetings between police, social authorities and school personnel have been arranged on a regular basis to discuss individuals who were considered at risk of radicalisation.

The Swedish government defines terrorism as a 'threat to human rights and democratic values' presented as 'our values'. Writing on it's homepage, the Swedish government offers this explanation of its position relating to terrorism and other forms of extremism:

"Our society must be formed by openness and respect for human rights and for democratic values. People must for instance move freely, participate in associations, utter their ideas, bear religious symbols without fear of being subjected to threat or violence. Violent extremism and terrorism threatens these basic values and we must keep fighting 
such threats. We cannot protect us against everything, but we will do whatever we can to protect ourselves" (CVE, 2018, https://www.cve.se/in-english.html).

According to the government's counter- terroism policy, it cannot be fought by 'isolated measures', but through cooperation between various governmental and public organs. Such actions are divided into three areas: Prevent, Stop and Obstruct terrorism. In early 2018 the government established the 'Center mot våldsbejakande extremism' (The Centre for Working Against Violent Extremism) (CVE) which detailed duties, and centralised all measures and actions to prevent radicalisation and extremism.

The preventional work of CVE included several public and civil actors such as, municipal social services and social work, schools, leisure activities, civil and religious associations. Besides police, security police and the criminal justice system should also be part of such preventive work by providing municipalities with accurate information and measures against radicalisation in society. The courts and legal system have also important role to play in preventing and combating terrorism, according to the Swedish government. Like the UK context, as the article goes on to explore, many caring professions as well as law enforcement agencies, have become immersed in countering violent extremism work.

The government has also ordered the police and the security police to include 'terrorism control' in their daily routines. Such measures however, are frequently used to control youth in marginalised areas who are considered as security problem for the country (Dahlstedt \& Lozic, 2017; Kamali, 2015; Sernhede, 2018). Securitisation of society in general and increasing control of youths with immigrant backgrounds have changed the traditional Swedish integration policy to be a policy of surveillance and security measures. Integration is much more about 'accepting our values' and 'way of lives' than living with plurality and diversity. The latter becoming 'nonmodern' and problematic discourses in the country. The discussion now moves on to consider the UK context.

\section{The UK policy context}

The UK's national counter terrorism strategy, known as CONTEST, was introduced post 9/11. Within this overall policy are what have become known as the four Ps; Prevent, Prepare, Pursue and Protect. PREVENT's aim was to prevent terrorism by identifying those at risk of 
radicalisation. This was to be achieved by the state working closely with communities where a risk of radicalisation was thought to be present. A significant change however, was the introduction of the Counterterrorism and Security Act (2015) which came into force in July 2015. The act now made it a statutory duty for social workers, and other prescribed professionals, to have "due regard" to the PREVENT duties.

PREVENT therefore requires social workers in the UK, to firstly identify those at risk of radicalisation and extremism and secondly, prevent people being drawn into terrorism. Of course, definitions of what is extremism and radicalisation are contentious and poorly defined. Indeed, a bill proposed in 2016, The Counter-Extremism and Safeguarding Bill, was not pursued in the end because of concerns about legal and definitional problems around the terms 'extremism' and 'non-violent extremism' which, raised serious concern that law abiding citizens, would be under an unacceptable level of state surveillance (Townsend, 2017).

The UK Government currently defines extremism as:

"vocal or active oppositions to fundamental British Values, including democracy, the rule of law, individual liberty and mutual respect and tolerance of different faith and beliefs. We also include in our definition of extremism, calls for the death of members of our armed forces, whether in this country or overseas" (HM Gov, 2014).

Radicalisation is defined by the Government as the:

"process by which a person comes to support terrorism and forms of extremism leading to terrorism, committing terrorist acts either abroad or on home ground" (HM Govt, 2014).

Similar to the Swedish situation, The UK government have defined British Values as:

"Democracy, the rule of law, individual liberty, mutual respect for and tolerance of those with different faiths and beliefs and for those without 


\section{Faith" (Gov Uk).}

As in Sweden, using the states existing collaborative arrangements between health, social care, youth offending and the police, locally led panels (known as CHANNEL panels) aim to:

- Identify individuals at risk of being drawn into terrorism

- Assess the nature and extent of that risk

- Develop the most appropriate support plan for the individuals concerned

- To safeguard children and adults being drawn into terrorism by intervening early before illegality occurs.

(HM Government, 2012).

Attendance at such panels is not compulsory however, but statistics reveal an ever greater number of people (adults and children) being referred to such panels. From 2006/2007 (when the scheme was a pilot scheme) 5 people were referred, compared with 1281 in 2012/2013 (National Chief Police Council, (NCPC) date unknown). The NCPC state that round 20\% of referrals were assessed as being 'vulnerable to being attracted towards terrorism'. Interestingly this NCPC states that whilst the the panels supports people of any faith, background or ethnicity:

"the greatest threat the UK currently faces is from terrorists who claim to act in the name of Islam, and who specifically target Muslims"

(NCPC, date unknown).

After 2013, the Home Office took over the collection of CHANNEL panel data. In the year 2015/2016, the number of referrals increased significantly to 7631 (Home Office, 2017) with $1,072(14 \%)$ '...deemed suitable through preliminary assessment to be discussed at a Channel panel' (Home Office, 2017:4). In terms of young people, in the same accounting period, $56 \%$ or referrals were aged 20 years or under. The report goes on to state:

"Those aged 20 years or under also made up the majority of the 1,072 individuals discussed at a Channel panel $(679 ; 63 \%)$ and the 381 individuals that received Channel support (273; 72\%) (Home Office, 2017:4). 
Of the total referrals to CHANNEL panels in 2015/2016, 65\% were for concerns around Islamic fundamentalism/extremism and $10 \%$ for concerns around right wing extremism. (Home Office 2017). The PREVENT policy has received widespread criticism in the UK from a wide range of academics, as well as key public figures and politicians For example, Thomas (2010) described the policy as 'failed and friendless'. Kundani (2014) identified significant concerns around PREVENT's relationship with the Muslim population in Britain, describing it as an opportunity for the British state to embed police and security services in marginalised communities with the express aim of surveillance for intelligence gathering purposes. McKendrick \& Finch (2016) argue that PREVENT represents a securitised turn in social policy, moving services such as Social Work, education and health away from the liberal, emancipatory origins towards a more sinister, intelligence gathering role on populations seen to be 'risky' or 'dangerous'. As Kamali (2015) has argued, such narratives are more readily applied to Muslim populations in Western countries and operate as a vehicle for Western countries to exaggerate concerns about the Muslim population which, in turn, provides fertile ground for Islamophobia to grow. This theme is developed by Miller \& Sabir (2012) who argue that Muslims in Britain are perceived to be 'insurgent'. The discussion now moves on to consider the methodology and methods utilized in this exploration.

\section{Methodology}

This study is a comparative research of the consequences of the policies of anti-terrorism and securitisation for many people with immigrant background in general and people with Muslim backgrounds in particular. Comparative studies can be conducted either of 'the most similar cases' or of 'the most different cases' (Tilly, 2001). Although this study compares securitisation policies in the UK and Sweden, who have very different colonial pasts and welfare systems, the two countries, as we will demonstrate have similar securitized social policies. There are some distinct advantages in undertaking a comparative policy analysis. For example a comparative study of child protection practices across Europe by Cooper et al, (1995), argued that comparative approaches give researchers a unique opportunity to identify new insights. Indeed, they argue further that in comparing different models, systems and cultures of social work it enables deeper critical reflection “ on how we do things ourselves' (1995, p. viii). Kantowicz (2005) argues that European comparative social work approaches offer researchers the opportunity to consider both universal and local expressions of social work which is an important consideration in this study in terms. Comparaative approaches are not without their limitations, indeed Shardlow and Wallis (2003) argue, there are distinct methodological problems with 
comparative approaches. Nonetheless there is merit in undertaking a comparative approach, not least to help identify similarities and differences.

This study uses a qualitative content analysis method (Graneheim \& Lundman, 2004) of media, political and public debates, journal articles, party programmes and governmental policies concerning anti-terrorism and securitisation. Such a methodological approach has helped us to find central categories and themes, and generate comprehensive understanding of its manifest and latent contents relevant to the aim and questions of this research. Additionally, given the paucity of social work research in this area, we deliberately chose to undertake an interdisciplinary approach. The discussion now moves on to consider the origins of CVE policies, and the underpinning ideological and historical contexts, which we argue, is a necessary activity to critique and reflect upon the ethical implications for social workers mandated to work with 'radicalisation' cases.

\section{Historical Context}

Suspicion and hostility against people with immigrant backgrounds in general (and against Muslims in particular) have long been part of many Western government's' control policies (Kamali, 2015; Sernhede, 2009), not least in promulgating the view that Muslims are enemies within, who cannot be trusted and so require controll. As Said (1978: 1-3) argues, 'the West' during centuries of confrontations with Muslims, who were encompassed in the concept of the Orient, portrayed the orient as polar-opposite of 'the West'. He criticises the way 'Western' scholars produced a depiction of 'West' as 'civilised' and 'advanced' in opposite to Asian and Middle Eastern cultures as 'barbaric' and 'backward' (1978: 72). Such colonial imaginations have been highly influential in classical social science literature, which continues to influence contemporary academic circles (Kamali, 2009).

Discrimination against Muslims is labeled by some scholars as 'anti-Muslim racism', which defines a type of hostility and enmity towards Muslims (Modood, 1997). It is however important to mention that Muslims were racialized prior to the September 11 attacks, not because of them (Cainkar 2009; Grewal 2014; Naber 2000). Although anti-Muslim attitudes and policies do not exclusively belong to the public policies of many Western countries' post September 11 events, Muslims' encounters with racism are tied to European colonialism and the Muslim presence in Iberia (Grosfoguel \& Mielants, 2006; Rana 2007). Although Sweden has not been a major Western colonial power, it has been highly engaged both in colonialism, slavery and 
racialisation of 'the others'. Sweden is the motherland of modern biological racism, developed by the Swedish botanist Carl von Linnaeus in seventeenth century. Anti-Muslimism has also been a part of modern racism in Sweden and is frequently used by the Swedish racist party, Sweden Democrats (Kamali, 2009).

Anti-Muslimism was however reinforced after September 11 attacks and some other major terrorist attacks in Spain, UK, France and Sweden. Establishment of the 'war on terror' and its national and international policies is in the interest of U.S. global hegemony and what Rana (2016) calls the 'terror-industrial complex', which is a web of domestic and global security agencies, surveillance mechanisms, police forces, militaries, and contractors. The 'war on terror' and terrorism are co-constitutive (Mamdani, 2004), since this racial project is grounded in the policies of empire ( $\mathrm{Ho}, 2004)$. The victims and subjects of the policies of 'war on terror' are positioned and identified in multiple intersecting ways, including by geography, skin color, clothing, gender, religion, and beliefs (Cainkar \& Selod, 2018). Thus, individuals and families with Muslim background have been subjected to structural racism and discrimination in their daily lives in Western countries.

Post-war racism in Sweden for example, like many other European countries including the UK, has changed its characteristics as a result of increasing anti-Muslimism in the country. This is a finding which is supported both by other studies (Kamali, 2009, 2015) and by the analysis of the collected material of this study. This anti-Muslim transformation can be viewed in both the racist party, Sweden Democrats (supported by more than 20 percent of the voters) and mainstream parties such as Moderate Party and even Social Democrat Party, in the election of 2018. Both Sweden Democrats and other mainstream parties (with the exception for the Greens and Leftists) were agreed about the necessity of policy to protect 'Us' against 'Them'. The emergence of racist groups called 'keep Sweden Swedish' (Bevara Sverige svenskt) in Sweden; and in Britain, Britain First, English Defence League, British National Party and the National Front have continued since the 1980s, to reinforce their public anti-immigrant propaganda and actions. Increasing immigration from Muslim countries to Sweden have reinforced anti-Muslim racism since late 1980 s and early 1990s. New racist parties, such as New Democracy (Ny Demokrati) and Sweden Democrats (Sverigedemokraterna), with clear anti-Muslim and anti-immigrant programmes appeared on the Swedish political scene. Although New Democracy disappeared in late 1990s, the anti-immigrant and anti-Muslim Sweden 
Democrats succeeded to gain electoral support in the post September 11 period and are today the third, and in some polls, the Second largest party in Sweden.

\section{Findings}

The results of this study show that sensationalised and 'thin narratives' contained in the media, political and public debates on Islam and Muslims in both Sweden and the UK, have not only reinforced and legitimised racism and anti-Muslimism subsequently framing Muslims with immigrant background as 'enemies within'. The war in Afghanistan and Iraq, as well as the question of 'honour killing' (as a Muslim legacy) and 'Islamic terrorism' in Europe, are frequently used as 'proof' of Muslim 'backwardness', cruelty and enmity to 'the West', i.e. to modernity and progress (see also, Kamali, 2015).

In terms of growing anti Muslim rhetoric in Sweden, for example, around the same time as the September 11 events, a Swedish girl from a Kurdish background, Fatima Sahindal, (a social work student of one of the authors of this paper) was murdered by her father (Hildebrandt, 2002). The murder was immediately used by anti-Muslim and cultural racist groups in Sweden as an example of honour-killing committed by Muslims. This was contrary to the fact that the entire Sahindal family were leftist with Kurdish backgrounds, and not exclusively Muslims. It was however the starting point of a major political and social mobilisation against the 'backward Muslim culture', which was considered incompatible with the 'modern Swedish culture'. Indeed, we can see similarities with the UK context, whereby former Prime Minister David Cameron, spoke of terrorist groups as an 'existential attack' on the British way of life, and referring to the challenges faced by Britain, described the matter in military language as 'a battle of our values and our narrative against their narrative' (BBC, 2015).

We have argued elsewhere (Kamali \& Jönsson, 2018, McKendrick \& Finch, 2017) that there is a militarised and securitised rhetoric emerging within CVE social policy. We argue that this narrative is not new, but a continuation of imperialist and colonial ideas that have at their core a belief in the supremacy and centrality of a Western centric doctrine that is suspicious of any other explanatory narratives that surround terrorism, racial violence or extremism. The role of the West, especially the UK as a colonial power responsible for the degradation and exploitation of non-Western countries remains significantly under recognised and ignored in the development of CVE policies, as well as the personal and familial experiences of individuals or groups who have borne the brunt of the violence inherent in colonialism which is often denied. 
Such denial can encourage feelings of anger, frustration and resentment, which if they are to be understood, require a parallel understanding of the role of the West as an oppressive and coercive power (Milne, 2001).

Britain's long and bloody colonial past, has led Gilroy (2006) to suggest that Britain has been left with a legacy of 'postcolonial melancholia' a situation where the complexities and challenges of Britain's past has left a malaise in contemporary understandings of the actions of Britain as a colonial and indeed a post colonial power. Colonialism saw Britain prosper through their appropriation of the material and natural wealth of the countries that were subjected to their rule. It fed resistance and violence and led to a series of conflicts which resulted in damage to the infrastructure and prosperity of countries, and saw the entrenchment of a political order driven by the belief of the supremacy of the white race. The legacy of Britain's colonialism has never fully been explored and remains a contested issue. For some, it is a source of pride and represents Britain as a word leader while for others it is a source of deep shame (see for example, Ahmed, 2013) . Of course, Britain's history of colonisation differs significantly from the Swedish context, but we also see in Sweden, the social and political legacy of racism and Western notions of superiority. This has become more pronounced in both Sweden and the UK, not least because of the increased flow of refugees.

PREVENT in the UK, and CVE in Sweden, with their binary understandings of terms like 'extremism', and its lack of attention to the political and social antecedents of individual behaviour represents the translation of this postcolonial melancholia into domestic policy. PREVENT denies the impact of Britain's colonial past on its present and is blind to its post colonial practices in the present. Instead it deploys a classic Neoliberal approach of individualising complex historical and contemporary phenomena through a securitised lens. The issue of existential threat emerges and comes to dominate the debate (Buzan, Webber, \& De Wilde, 1998). Indeed, such is the febrile atmosphere created by this approach, the UK media reported that a 4 year old Muslim child was threatened with referral to PREVENT when the nursery worker thought the child has said 'cooker bomb' when in fact he was referring to a cucumber (Quinn, 2016). This state of raised professional anxiety is becoming increasingly normalised in policy and practice. Additionally, there remains a significant gap in our empirical knowledge of the impact on families and social workers who live and work inside the PREVENT/CVE environment. 


\section{Discussion - Ethical Issues for Social Work}

Concern has been raised in both Sweden and the UK (see for example, Jönsson, 2019; Kamali, 2015; Lauri, 2016; Mckendrick \& Finch, 2017; Sernhede, 2018; Stanley \& Guru, 2015 ) that such policies have quietly, and with little controversy, slipped into the routine tasks and practices of social work. We have been concerned at the lack of critical debate within both social work practice and academia about this policy, not least the extent to which the statutory duty might present a potential conflict with fundamental social work values. We are also concerned about the resulting policy as well as the research vacuum, and a lack of knowledge about what is, or ought to be, good practice in this area of social work practice.

Indeed, concerns have been further raised by Ragazzi (2016) that policies such as PREVENT have created 'an unprecedented blurring of social and security policies' that has supported a shift in social work activity towards a securitising narrative that is underpinned by ideas of 'suspect communities' (Hillyard 1993). Originally used as a way of exploring attitudes towards the Irish community in Britain, the notion of suspect communities has been applied to the Muslim community in Britain as a result of the war on terror. Increasingly suspect communities are subject to a series of surveillance led activities that utilise public servants to monitor and report on a variety of activities that might otherwise been seen as relatively innocent or equally associated with the emotional, personal and social growth of young people. As Williams (2016) has identified there is a concern that the behaviour of some young people in exploring the political and social environment that exists, may be accelerated towards a securitised response when such a response is neither required or indeed helpful. Further, the need for social workers to maintain confidentiality to support the development of trusting, longitudinal relationships is likely to be compromised if the blurring of the lines between the social and the security arms of the state continues. It may also have the opposite effect by reinforcing a sense of anger and frustration at the state which is unfairly imposing itself on the young person.

The building of trust between the state and those caught in the suspect community narrative is equally ethically challenging. Vitale (2017) describes how policing has advanced into new professional environments and territories despite a reduction in resources available to them. Central to this is the pre criminal space where police operate in communities or with groups who have not committed any offence but where concern over their behaviour exists; the most used 
vehicle for this is through multi disciplinary working arrangements that see police (or in this case security officers) entering the social work field in a decisive way. Thus security officers and the police are working closely in a preventative capacity as we see in both the Swedish and Uk context. As Ragazzi (2016) notes however, this serves to a further blurring of relationships between the welfare professions and the police and security services.

Finch \& McKendrick (2019) describe this as a form of 'securitised safeguarding'; an emerging area of practice as police, social work and the security services act in concert to (ostensibly) reduce violent extremism. We note here that this has been widely accepted in the UK and Sweden, and there appears to us, a significant lack of criticality about this emerging practice direction. We seek therefore, to encourage an increase in discussion and academic debate and research in this area, and we note with concern, new forms of public service actors policing, which a shift from policing crime and criminality, to policing behaviours and attitudes.

As we can see, both Sweden and the UK, have developed CVE policies in the same neo liberal direction (albeit it at different rate) using the same rhetorical linguistic devices, namely the state sponsored promotion of the continued othering of particular immigrant and Muslim individuals, groups and communities. Indeed, blurring the distinctions between Muslim and immigrants is a further linguistic device. We note in both countries the surreptitious and state mandated (and indeed requirement) to involve a range of caring professions in counter terrorism work and we also recognise that the growth in countering violent extremism develops in tandem with the growth of a new right wing political discourse in both countries, alongside a shrinking of the welfare state, across Europe and North America. The emerging securitisation of social policy described by Ragazzi (2016) is consistent across Sweden and Britain indicating a new and concerning development for social work. Indeed it may be the case that what we are seeing is the development of securitising policies (which bring with them the otherisation of ethnic groups, particularly Muslims and more specifically young Muslims) which play to the insecurity of the general population by emphasising a narrative of 'suspect communities'. There are a number of inherent dangers in this approach; is its denial of Western complicity in this through its current and previous colonial activities and the depiction of suspect communities as criminal, dangerous or threatening can influence public opinion and providing fertile soil for continued policies that promote concerns over race and immigration, examples of which are to be found both in policy and political rhetoric in both Sweden and Britain. 
It is important to note that these are the views of, in the main, democratically elected politicians in many Western countries indicating a shift in political thinking to a Neoliberal and Neoconservative paradigm, we argue that such a shift is mobilised by a deliberate planned and orchestrated construction of Muslims as dangerous, unpredictable, violent others who require an increased and robust set of responses from the spectrum of public services. Britain's PREVENT policy is explicit in naming public service professionals such as Nurses, Social Workers and Prison Officers as the front line of defence against violent extremism. The development of the multi agency CHANEL panels with their direct link to security services are a device to embed securitisation in the execution of otherwise (potentially) liberatory actions of public servants. O'Donnell $(2015,2017)$ describes these challenges from an educational perspective noting how PREVENT serves to impact on students willingness to express their ideas and perspectives for fear of being deemed 'extreme' while Rizq (2017) explores how PREVENT operates a form of exceptionalism that breeches the confidentiality of the psychotheraputic 'space'. McKendrick \& Finch (2016) further consider how PREVENT impacts on the ability to form meaningful and trusting relationships with people who use social work services when the spectre of coercive power is used as a proxy by PREVENT.

Important questions are thus raised about what is, or ought to be social workers roles in matter of state security by the identification, prevention and management of extremism and radicalisation? A further question to arise therefore, is to what extent, social workers involvement in counter extremism policies, can be considered as 'normal' welfare or safeguarding activities, or is it indeed, something more sinister and concerning. In other words, is this incursion into counter terrorism work, a natural development of social work as agents of an oppressive state, a natural outcome of the on-going care vs control, or does it signify a new low for social work in neo liberal western regimes. On a positive note however, there are nonetheless, critical voices against the demands put on social workers to be the agent of control and not agents of change and social justice, not only in Sweden, but also in all Nordic countries (Kamali \& Jönsson, 2018) and we note the beginnings of critical practitioner voices emerging in the UK from both social work and a range of professions.

\section{Conclusion}

The UK and Swedish CVE policies have been developed within a historical context of colonisation, racism and othering which have resulted in the creation of suspect communities. 
The study shows that such policies have very severe implications for social work policy and practice across Europe and further afield, not least ensuring the major body of social work (and other caring or emancipatory professions) are fully submerged in the state security apparatus. Such work requires a critical response from social work practitioners and academics and yet we remain concerned at the little discussion to date on this important issue, one that is not without its own inherent dilemmas and tensions. Such policies do not operate in a vacuum, they are a produce of historical forces and the continued neoliberal drive of many western democracies yet if we are to remain true to social work values, we must critically question and debate what is or should be our role (if any) in CVE work without being passive actors in a policy environment which reproduces stigmatisation, oppression, suspect communities, anti-Muslimism and other forms of racism.

\section{Bibliography}

Ahmed, S. (2013) The Cultural Politics of Emotion, London, Routledge

Barrett, D. (2015) "Islamist indoctrination of London schoolgirl in family home was as bad as sex abuse, judge rules" The Telegraph, available from https://www.telegraph.co.uk/news/uknews/terrorism-in-the-uk/11817029//slamistindoctrination-of-London-schoolgirl-in-family-home-was-as-bad-as-sex-abuse-judgerules.html (accessed 24/8/18)

BBC (2015) Cameron: Combat Appalling Radical Narrative of IS, Today Programme, Radio 4 http://www.bbc.co.uk/programmes/p02vw70k (accessed 20/3/17)

Buzan, B., Waever, O.,. and De Wilde, J,. (1998) Security, A New Framework for Analysis. Lynne Reiner Publishers

Cainkar, L.A (2009) Homeland Insecurity: The Arab American and Muslim American Experience after 9/11. New York: Russell Sage 
Cainkar, L. and Selod S. (2018) 'Review of Race Scholarship and the War on Terror'. Sociology of Race and Ethnicity, Vol 4(2), pp: 165-177.

Cooper, A., Hetherington, R., Baistow, K., Pitts, J., \& Spriggs, A. (1995). Positive child protection _ A view from abroad. London: Russell House.

CVE (2018) available at: https://www.cve.se/in-english.htm

Dahlstedt, M., \& Lozic, V. (2017). Managing urban unrest: problematising juvenile delinquency in multi-ethnic Sweden. Critical and Radical Social Work, Vol 5 (2), pp:207-222.

Eliassi, B. (2015). Constructing Cultural Otherness within the Swedish Welfare State: The Cases of Social Workers in Sweden. Qualitative Social Work, Vol. 14 (4), pp:554-571.

Finch, J. and McKendrick, D. (2019) Securitising Social Work: Counter Terrorism, Extremism and Radicalisation, in Webb, S. (ed) The Routledge Handbook of Critical Social Work, London, Routledge

Gilroy, P., (2003). There Ain't No Black in the Union Jack. London: Routledge.

Graneheim, U.H. \& Lundman, B. (2004). Qualitative content analysis in nursing research: Concepts, procedures and measures to achieve trustworthiness. Nurse Education Today 24(2): 105-112.

Grewal, Z. (2014) Islam Is a Foreign Country. New York: NYU Press.

Grosfoguel R. and Mielants E. (2006) "The Long-Durée Entanglement between Islamophobia and Racism in the Modern/Colonial Capitalist/Patriarchal World-system: An Introduction". Human Architecture, Vol 5(1) : Article 2 available from https://scholarworks.umb.edu/humanarchitecture/vol5/iss1/2/ (access 5/11/18) 
Herz M. (2016) Socialt arbete, pedagogik och arbete mot så kallad våldsbejakande extremism En översyn (Social work, pedagogy and working against so called violent extremism - A review) Göteborg: Segerstedtinstitutet.

Hildebrandt, J. (2002) Honour' killing in Sweden silences courageous voice on ethnic integration, The Guardian online, available from https://www.theguardian.com/theguardian/2002/jan/31/guardianweekly.guardianweekly1 (accessed 2/7/18)

Hillyard, P. (2005) 'The "War on Terror”: lessons from Ireland', European Civil Liberties Network, ecln.org

Ho, E. (2004) "Empires through Diasporic Eyes: A View from the Other Boat." Comparative Study of Society and History Vol 46 (1) pp:210-46.

Hoffman, B. (2006) Inside Terrorism (expanded and revised edition) New York, Columbia University Press,

Home Office (2017) Individuals referred to and supported through the Prevent Programme, April 2015 to March 2016, Statistical Bulletin 23/17, HMSO, London, available from https://assets.publishing.service.gov.uk/government/uploads/system/uploads/attachmen $\mathrm{t}$ data/file/677646/individuals-referred-supported-prevent-programme-apr2015mar2016.pdf accessed 6/7/18

Horgan, J. (2014) The Psychology of Terrorism (2 ${ }^{\text {nd }}$ Edition) New York, Routledge Jönsson, J.H. (2013). Social work beyond cultural otherisation. Nordic Social Work Research, 3(2): 159-167.

Jönsson, J.H. (2015). The contested field of social work in a retreating welfare state: the case of Sweden. Critical and Radical Social Work, 3(3): 357-374. 
Jönsson, J.H. (2019). Servants of a 'sinking Titanic' or actors of change?: contested identities of social workers in Sweden. European Journal of Social Work, 22(2): 212-224.

Kamali, M. (2009). Racial Discrimination: Patterns and Politics. London: Routledge.

Kamali, M. (2015). War, Violence and Social Justice: Theories for Social Work. London:

Routledge.

Kamali, M., \& Jönsson, J.H. (Eds.). (2018). Neoliberalism, Nordic Welfare States and Social Work: Current and Future Challenges. London: Routledge.

Kantowicz, E. (2005). Dilemmas in comparative research of education for social workers in Europe. European Journal of Social Work, 8(3), $297 \_309$.

Koomen, W. and van der Pligt, J. (2016) The Psychology of Radicalization and Terrorism, Abingdon, Routledge.

Kundnani, A. (2007). Integrationism: the politics of anti-Muslim racism. Race \& Class, 48(4): 2444.

Lauri. M (2016) Narratives of Governing: Rationalization, responsibility and resistance in social work. Umeå: Umeå University.

Mamdani M. (2004) Good Muslim, Bad Muslim: America, the Cold War, and the Roots of Terror. New York: Pantheon.

McKendrick, D. and Finch, J. (2017) Downpressor man: Securitsation, Safeguarding and Social Work, Critical and Radical Social Work, doi.org/10.1332/204986017X15029697482460

McKendrick, D. and Finch, J. (2016) "Under Heavy Manners: Social Work, Radicalisation, Troubled Families and Non-linear War, British Journal of Social Work. Vol 47 (2): pp:308-324.

Milne, S. (2001) "They can't see why they are hated”, The Guardian Newspaper, available from 
https://www.theguardian.com/politics/2001/sep/13/september11.britainand911

accessed $1 / 8 / 18$

Modood, T. (1997) Difference, Cultural Racism and Anti-racism. In: P. Werbner and T. Modood (eds.) Debating Cultural Identity. London: Zed Books.

Naber N. (2000) "Ambiguous Insiders: An Investigation of Arab American Invisibility." Ethnic and Racial Studies Vol 23 (1) pp:37-61.

National Chief Police Council (date unknown) National Channel referral figures, available from http://www.npcc.police.uk/FreedomofInformation/NationalChannelReferralFigures.aspx accessed 6/7/18

Nguyen N. (2016) A Curriculum of Fear: Homeland Security in US Public Schools. Minneapolis: University of Minnesota Press.

O'Donnell, Aislinn. (2016) Securitisation, Counterterrorism and the Silencing of Dissent: The Educational Implications of Prevent, British Journal of Educational Studies, Vol 64:(1) pp: 53-76, Quinn, B. (2016) 'Nursery raised fears of radicalisation over boy's cucumber drawing', The Guardian Online, available from https://www.theguardian.com/uknews/2016/mar/11/nursery-radicalisation-fears-boys-cucumber-drawing-cooker-bomb (accessed 10/9/18)

Ragazzi, F. (2017). Countering terrorism and radicalisation: Securitising social policy? Critical Social Policy, Vol37 (2), pp:163-179. https://doi.org/10.1177/0261018316683472

Rana J. (2007) “The Story of Islamophobia”. Souls, Vol 9(2): pp148-61.

Rana J. A. (2016) "The Racial Infrastructure of the Terror-industrial Complex." Social Text, Vol 34(4) pp:111-38.

Rizq, R. (2017) 'Pre-crime', Prevent, and practices of exceptionalism: Psychotherapy and the new norm in the NHS, Psychodynamic Practice, Vol23:4, pp:336-356, DOI: $\underline{10.1080 / 14753634.2017 .1365005}$ 
Said, E. (1978). Orientalism . London: Routledge and Kegan Paul.

Sernhede, O. (2009). Alienation is my Nation. Stockholm: Ordfront.

Sernhede, O. (2018). Urban Marginality, social mobilisation and youth work in the shadow of neoliberalism and segregation. In M. Kamali \& J.H. Jönsson (Eds.), Neoliberalism, Nordic Welfare States and Social Work: Current and Future Challenges (pp. 238-248). London:

Routledge.

Smelser, N.J. (2007) The Faces of Terrorism: Sociological and Psychological Dimensions , Princeton, Princeton University Press

Stanley, T., \& Guru, S. (2015). Childhood Radicalisation Risk: An Emerging Practice Issue. Practice: Social Work in Action I, 1-14. doi:10.1080/09503153.2015.1053858

Swedish Government (2018) available from (https://www.regeringen.se/regeringenspolitik/sveriges-strategi-mot-terrorism-och-arbete-mot-valdsbejakande-extremism) accessed $1 / 11 / 18$

Tilly, Charles (2001) "Mechanisms in Political Processes." Annual Review of Political Science 4:21-41.

Townsend, M. (2017) Theresa May's counter-terrorism bill close to 'sinking without trace', The Guardian online, available from https://www.theguardian.com/politics/2017/jan/29/theresa-may-counter-terrorism-billsinking-without-trace-extremism-british-values accessed 16/2/18

Vitale, Alex., S., (2017) The End of Policing, London, Verso Books https:/lec.europa.eu/home-affairs/sites/homeaffairs/files/what-wedo/networks/radicalisation awareness network/ranpapers/docs/ran young policy recommendations 032018 en.pdf 
